GRASAS Y ACEITES 69 (3)

July-September 2018, e261

ISSN-L: 0017-3495

https://doi.org/10.3989/gya.1225172

\title{
A Mediterranean-style breakfast increases postprandial serum $\alpha$-tocopherol levels in lean and obese individuals
}

\author{
S. García-Rodríguez ${ }^{\mathrm{a}}$, L. Sinausia ${ }^{\mathrm{a}}$, C. Barragán ${ }^{\mathrm{a}}$, E. Montero ${ }^{\mathrm{b}}$ and J.S. Perona ${ }^{\mathrm{a},}$ \\ ${ }^{a}$ Food and Health, Instituto de la Grasa-CSIC, Seville, Spain \\ ${ }^{\mathrm{b}}$ Emergency unit, HHUU Virgen del Rocío, Seville, Spain. \\ ${ }^{\square}$ Corresponding author: perona@ig.csic.es
}

Submitted: 13 December 2017; Accepted: 06 April 2018

SUMMARY: The aim of this study was to compare the variations in the concentrations of tocopherols and retinol in obese adults in the postprandial state after the intake of a Mediterranean or Western-style breakfast. The study was designed as a randomized, controlled intervention trial in the postprandial state, for which 24 male adults (12 obese and 12 of normalweight) were recruited. After a fat challenge, blood samples were collected at different times postprandially and $\alpha$-tocopherol, $\gamma$-tocopherol and retinol concentrations were determined in serum by HPLC. The Mediterranean-style meal produced a greater increase in serum $\alpha$-tocopherol levels in both obese and normal-weight subjects, compared to the Western-style meal, indicating that the composition of the food affects the concentration of tocopherols in the postprandial state. However, the serum concentrations of $\gamma$-tocopherol and retinol remained unmodified. In conclusion, the presence of $\alpha$-tocopherol in the meal could contribute to the protection of the Mediterranean-style meal against atherosclerosis in the postprandial state.

KEYWORDS: $\alpha$-tocopherol; Breakfast; Mediterranean-style meal; Obesity; Postprandial; Western-style meal

RESUMEN: El desayuno de estilo mediterráneo aumenta los niveles de a-tocoferol sérico posprandial en individuos delgados y obesos. El objetivo de este estudio fue comparar las variaciones en la concentración de tocoferoles y retinol en adultos obesos en el estado postprandial tras la ingesta de un desayuno mediterráneo u occidental. Consiste en un ensayo de intervención aleatorio y controlado, en el que participaron 24 adultos varones (12 obesos y 12 normopeso). Tras la ingesta de dichas comidas, se determinaron las concentraciones de $\alpha$-tocoferol, $\gamma$-tocoferol y retinol en el suero de las muestras sanguíneas mediante HPLC. La comida de estilo mediterráneo aumentó los niveles séricos de $\alpha$-tocoferol en sujetos obesos y de peso normal, en comparación con una comida de estilo occidental, lo que indica que la composición del alimento afecta a su concentración sérica. Sin embargo, referente al $\gamma$-tocoferol y retinol, permanecieron sin modificaciones. En conclusión, la presencia de $\alpha$-tocoferol en una comida de estilo mediterráneo podría contribuir a la protección contra la aterosclerosis en el estado postprandial.

PALABRAS CLAVE: a-tocoferol; Comida de estilo Mediterráneo; Comida Occidental; Desayuno; Obesidad; Postprandial

ORCID ID: García-Rodríguez S https://orcid.org/0000-0003-2096-9655, Sinausia L https://orcid.org/0000-00027605-5310, Barragan C https://orcid.org/0000-0003-4622-2824, Montero E https://orcid.org/0000-0002-1751-3545, Perona JS https://orcid.org/0000-0001-5919-993X

Citation/Cómo citar este artículo: García-Rodríguez S, Sinausia L, Barragan C, Montero E, Perona JS. 2018. A Mediterranean-style breakfast increases postprandial serum $\alpha$-tocopherol levels in lean and obese individuals. Grasas Aceites 69 (3), e261. https://doi.org/10.3989/gya.1225172

Copyright: (C2018 CSIC. This is an open-access article distributed under the terms of the Creative Commons Attribution 4.0 International (CC BY 4.0) License. 


\section{INTRODUCTION}

Obesity is considered one of the main public health concerns in Western countries as it gives rise to other conditions, such as diabetes or cardiovascular disease. Obesity has also been associated with systemic inflammation and increased oxidative stress, which lead to decreased $\alpha$-tocopherol bioavailability, increasing the requirements for this vitamin in obese individuals (Traber et al., 2017). $\alpha$-Tocopherol is capable of protecting cell membranes and low density lipoproteins (LDL) from lipid peroxidation (Trpkovic et al., 2015), an alteration that is necessary to trigger atherogenesis (Cabello-Moruno et al., 2007). LDL from obese subjects are more susceptible to oxidation and thus, may require more antioxidants for protection against oxidative stress (Maruyama et al., 2013). The possible relevance of postprandial $\alpha$-tocopherol depletion and its relation with lipid peroxidation in diabetic individuals has been suggested (Manuel-Y-Keenoy et al., 2004). In addition, it has been observed that the intake of antioxidant supplements, such as $\alpha$-tocopherol, has a greater effect on oxidative stress in subjects with postprandial anomalies such as hyperglycemia and hyperlipidemia, which are very common in obese individuals (Plotnick et al., 1997).

There is also considerable evidence that vitamin A homeostasis is involved in regulating body fat and blood glucose levels. It appears that altered levels of circulating retinol have a relevant role in the modulation of endocrine hormones and gene transcription associated to lipid and glucose metabolism (Mody 2017). Subjects with a higher adherence to the Mediterranean diet have higher plasma concentrations of $\beta$-carotene and $\alpha$-tocopherol compared to other dietary patterns, whereas retinol levels remain unchanged (Bach-Faig et al., 2006). However, the effect of a Mediterranean-style breakfast on postprandial serum concentrations of tocopherols and retinol has not been addressed to date.

This study was designed to determine whether plasma concentrations of retinol and tocopherols $(\alpha$-tocopherol and $\gamma$-tocopherol) are altered in the postprandial state in obese individuals and whether a Mediterranean-type breakfast can contribute to restoring such concentrations.

\section{MATERIALS AND METHODS}

\subsection{Subjects}

Twenty-four adult male subjects (22-56 yearsold), without a history of digestive or metabolic disorders, were recruited for the study by placing announcements in online social networks and among acquaintances of the research team in the city of Seville (Spain). Sample size was calculated by power analysis, considering a type 1 error $(\alpha)=0.05$ and a power $(1-\beta)=0.9$ and the resulting minimum number was 10 individuals per group. Subjects were classified as normal-weight or obese using BMI cut-off points according to age and sex. Twelve adults were obese $\left(\mathrm{BMI}>30 \mathrm{Kg} / \mathrm{m}^{2}\right)$ and 12 normal-weight (BMI $=20-25 \mathrm{Kg} / \mathrm{m}^{2}$ ). A written consent form, which was approved by the Institutional Committee on Human Research of HHUU Virgen del Rocío (Seville, Spain), was obtained from the participants. The consent form and the protocol were in accordance with the institutional and national ethical standards for human experimentation and the Helsinki declaration of 1975 (revised in 2000). The study was registered in clinicaltrials. gov (NCT01518803).

\subsection{Study design}

The study was designed as crossed-over to test the effect of two variables, obesity and meal composition, on $\alpha$-tocopherol, $\gamma$-tocopherol and retinol serum postprandial concentrations. Participants were asked to have a low-fat dinner the evening prior to the postprandial assay and to abstain from alcohol drinking and smoking for $24 \mathrm{~h}$. After an overnight fast (12 h), a cubital vein was catheterized and a baseline blood sample was taken immediately before consumption of the first test meal, which was consumed in less than 15 minutes. Blood samples were collected at baseline $(0 \mathrm{~h})$ and at $2 \mathrm{~h}$ and $4 \mathrm{~h}$ after the intake of the meals. During the course of the experiment, the subjects were allowed to drink water and to undertake only light activities. The subjects consumed a Mediterranean breakfast consisting of 3 slices of brown bread $(71 \mathrm{~g}), 200 \mathrm{~mL}$ of skimmed milk, $250 \mathrm{~mL}$ of orange juice and $20 \mathrm{~g}$ of mashed tomato and $57 \mathrm{~g}$ of olive oil. The composition of the meal was selected to reflect the habitual breakfast consumption in southern Spain. Olive oil was kindly supplied by Oleicola El Tejar, S.A. (El Tejar, Cordoba, Spain). The Western breakfast consisted of $55 \mathrm{~g}$ of butter, three slices of brown bread and a glass of skimmmed milk $(200 \mathrm{ml})$ with cocoa powder $(20 \mathrm{~g})$. The main composition of the meals is indicated in Table 1. The composition of $\alpha$-tocopherol and retinol in olive oil and butter was determined as described below for serum and is depicted in Table 2. The olive oil was directly dissolved in hexane but the butter was first heated at $37^{\circ} \mathrm{C}$ to break the emulsion. The tocopherol and retinol contents of the other components of the meals were recorded from the Spanish database of food composition (Spanish Agency for Consumer Affairs, Food Safety and Nutrition). 


\subsection{Baseline biochemical analyses}

Serum glucose, cholesterol and triglycerides were determined by enzymatic colorimetric methods on a Roche/Hitachi System analyzer (Roche Diagnostic, Mannheim, Germany). Serum HDLcholesterol was measured by a direct enzymatic method (HDL-C-plus 2nd generation, Roche Diagnostics, Mannheim, Germany) on a Roche/ Hitachi System analyzer (Roche Diagnostic) and LDL cholesterol was estimated by the Friedewald equation (Friedewald et al., 1972). Insulin was measured by immunoassay (Abbott Laboratories, Maidenhead, UK) and the Homeostasis Model Assessment of the insulin resistance (HOMA-IR) score was calculated using the HOMA Calculator software (Diabetes Trial Unit, Churchill Hospital, Oxford, UK).

TABLE 1. Nutrient compositions of the experimental meals.

\begin{tabular}{lcc}
\hline & Western breakfast & $\begin{array}{c}\text { Mediterranean } \\
\text { breakfast }\end{array}$ \\
\hline Energy (kJ) & 1963 & 2022 \\
Protein (g) & 14 & 15 \\
Carbohydrates (g) & 53 & 62 \\
Sucrose (g) & 26 & 26 \\
Fats (g) & 53 & 57 \\
SFA (g) & 32 & 8 \\
MUFA (g) & 15 & 44 \\
PUFA (g) & 2 & 5 \\
Fiber (g) & 6.4 & 7.0 \\
Cholesterol (mg) & 104 & 0 \\
Tocopherols (mg) & 1.70 & 45.85 \\
\hline
\end{tabular}

SFA, saturated fatty acids; MUFA, monounsaturated fatty acids; PUFA, polyunsaturated fatty acids.

\subsection{Determination of tocopherols and retinol}

Liposoluble vitamins were extracted from $500 \mu \mathrm{L}$ of serum as follows: $500 \mu \mathrm{L}$ of ethanol and $1 \mathrm{~mL}$ of hexane were added sequentially. The mixture was centrifuged $\left(3500 \mathrm{rpm}, 15^{\circ} \mathrm{C}\right.$ for $\left.10 \mathrm{~min}\right)$ and the supernatant was collected. Hexane was evaporated under a stream of nitrogen and the vitamins were re-dissolved in choloroform/methanol (2:1, v/v) for injection into the the HPLC system. This system consisted of a reversed-phase column (Novapack) and an elution system composed of methanol/acetonitrile (chloroform $(9: 78: 13, \mathrm{v} / \mathrm{v} / \mathrm{v})$ which run isocratically. A photodiode array detector (PAD 996, Waters) was used for $\alpha$-tocopherol, $\gamma$-tocopherol and retinol detection at $290 \mathrm{~nm}$ ( $\alpha$-tocopherol and $\gamma$-tocopherol) and $325 \mathrm{~nm}$ (retinol), respectively. These compounds were identified using commercial standards and quantified by means of external standard.

\subsection{Statistical analysis}

The results were expressed as mean \pm SEM. Data analyses were performed with the GraphPad Prism $^{\circledR} 5$ statistical package (GraphPad Software Inc., San Diego, CA). The baseline statistical significance of anthropometric measurements, serum biochemical determinations and serum $\alpha$-tocopherol, $\gamma$-tocopherol and retinol concentrations between obese subjects and their normalweight counterparts were assessed with the Student's t test. The same comparisons were made for the incremental AUC (iAUC) values which were calculated from the postprandial curves. A 2x2 ANCOVA test was applied on iAUC values using the meals (Mediterranean and Western) and body size as the independent variables. For those comparisons which resulted in significantly different, a Student's t test was used to compare the iAUC values. Differences were considered statistically significant at $\mathrm{p}<0.05$.

TABLE 2. $\alpha$-Tocopherol and retinol equivalent compositions of the experimental meals.

\begin{tabular}{|c|c|c|c|c|}
\hline & $\begin{array}{c}\text { Western } \\
\text { breakfast }\end{array}$ & $\begin{array}{c}\text { Mediterranean } \\
\text { breakfast }\end{array}$ & $\begin{array}{c}\text { Western } \\
\text { breakfast }\end{array}$ & $\begin{array}{c}\text { Mediterranean } \\
\text { breakfast }\end{array}$ \\
\hline & \multicolumn{2}{|c|}{$\alpha$-Tocopherol (mg) } & \multicolumn{2}{|c|}{ Retinol $(\mu \mathrm{g})$} \\
\hline Brown bread & 0.47 & 0.47 & ND & ND \\
\hline Skimmed milk & 0.02 & 0.02 & ND & ND \\
\hline Orange juice & - & 0.43 & - & 182.5 \\
\hline Tomato & - & 0.18 & - & 16.4 \\
\hline Olive oil & - & 44.75 & - & 19.4 \\
\hline Cocoa powder & 0.11 & - & 0.2 & - \\
\hline Butter & 1.10 & - & 430.7 & - \\
\hline Total & 1.70 & 45.85 & 430.9 & 218.3 \\
\hline
\end{tabular}

ND: not detected. - : ingredient not present in the meal. 


\section{RESULTS}

\subsection{Anthropometric characteristics and serum lipid, glucose, insulin and adipokine concentrations}

Table 3 shows the anthropometric characteristics and fasting serum concentrations of lipids, glucose, insulin and liposoluble vitamins. Compared to their normal-weight subjects, obese individuals presented higher values of BMI, serum triglycerides, total and LDL-cholesterol, glucose, and systolic pressure values, but not diastolic blood pressure. In addition, this group presented lower HDL-cholesterol concentrations. No significant difference was observed for baseline serum concentrations of $\alpha$-tocopherol and $\gamma$-tocopherol but the retinol content was higher in the obese group.

\subsection{Postprandial concentrations of $\alpha$-tocopherol and $\gamma$-tocopherol and retinol}

The postprandial concentrations of the liposoluble vitamins analyzed are depicted in Figure 1. The values were normalized with the concentrations at 0 h. For all compounds, except for $\gamma$-tocopherol in the obese group, significant differences were observed $4 \mathrm{~h}$ after the intake of the meals but not at $2 \mathrm{~h}$. The Mediterranean-style breakfast increased $\alpha$-tocopherol concentrations at $4 \mathrm{~h}$ postprandially in both groups (Figures 1A and 1B). In contrast, this breakfast reduced the content of $\gamma$-tocopherol (Figure 1C) and retinol (Figure 1E) at that time point compared with the Western-style meal but only in the normalweight group. In obese subjects, no differences were found for $\gamma$-tocopherol between meals (Figure 1D) and the Mediterranean meal increased the content of retinol (Figure 1F).

As shown in Figure 2, $\alpha$-tocopherol postprandial iAUC values were significantly higher in both groups after the intake of the Mediterranean meal (Figure 2A and 2B). In fact, $\alpha$-tocopherol values were affected by the meal only, and not by body size (Table 4). In contrast, no significant differences were observed in iAUC values for $\gamma$-tocopherol and retinol after the intake of the experimental meals (Figures 2C, 2D, 2E and 2F). These values were not affected by any of the two variables studied (meal and body size) according to 2X2 ANCOVA (Table 4).

\section{DISCUSSION}

We report here that a Mediterranean-style meal can increase postprandial serum $\alpha$-tocopherol levels in both obese and normal weight subjects compared to a Western-style meal. The content of $\alpha$-tocopherol was higher in the Mediterranean breakfast, mainly due to its content in olive oil (Table 2), but also to orange juice and tomato. Ascorbic acid is also present in orange juice and tomato but its role in protecting $\alpha$-tocopherol from oxidation is still controversial. Porkkala-Sarataho et al., (1996) reported that in contrast to $\alpha$-tocopherol, supplementation with ascorbic acid did not have any significant

TABLE 3. Anthropometric characteristics and baseline serum concentrations of lipids, glucose, insulin and liposoluble vitamins.

\begin{tabular}{|c|c|c|c|}
\hline & Normal-weight & Obese & $\mathbf{p}$ \\
\hline Age (y) & $27.3 \pm 2.9$ & $35.8 \pm 3.5$ & 0.075 \\
\hline Weight (kg) & $74.9 \pm 2.3$ & $112.9 \pm 3.9$ & $<0.001$ \\
\hline Height $(\mathrm{cm})$ & $179.6 \pm 2.0$ & $180.8 \pm 1.5$ & 0.778 \\
\hline BMI $\left(\mathrm{kg} / \mathrm{cm}^{2}\right)$ & $23.2 \pm 0.3$ & $34.7 \pm 1.4$ & $<0.001$ \\
\hline Systolic Pressure (mmHg) & $110.9 \pm 3.7$ & $130.8 \pm 2.2$ & $<0.001$ \\
\hline Diastolic Pressure (mmHg) & $68.9 \pm 2.1$ & $74.5 \pm 2.9$ & 0.120 \\
\hline Glucose $(\mathrm{mg} / \mathrm{dL})$ & $73.7 \pm 1.4$ & $83.6 \pm 2.4$ & 0.002 \\
\hline Insulin (mU/ml) & $4.9 \pm 0.8$ & $12.6 \pm 1.2$ & $<0.001$ \\
\hline Triglycerides (mg/dl) & $78.7 \pm 7.1$ & $129.7 \pm 17.4$ & 0.013 \\
\hline Cholesterol (mg/dl) & $172.5 \pm 9.4$ & $202.9 \pm 10.0$ & 0.030 \\
\hline LDL-c (mg/dl) & $94.7 \pm 5.6$ & $158.7 \pm 4.8$ & $<0.001$ \\
\hline HDL-c (mg/dl) & $57.5 \pm 2.8$ & $45.9 \pm 2.5$ & 0.005 \\
\hline$\alpha$-Tocopherol $(\mu \mathrm{g} / \mathrm{ml})$ & $9.87 \pm 0.73$ & $10.48 \pm 1.69$ & 0.703 \\
\hline$\gamma$-tocopherol $(\mu \mathrm{g} / \mathrm{ml})$ & $0.17 \pm 0.03$ & $0.14 \pm 0.02$ & 0.414 \\
\hline $\operatorname{Retinol}(\mu \mathrm{g} / \mathrm{ml})$ & $0.45 \pm 0.04$ & $0.73 \pm 0.10$ & 0.016 \\
\hline
\end{tabular}

Data are expressed as mean $\pm \mathrm{SEM} ; \mathrm{n}=12$. BMI: body mass index. LDL-c, low-density-lipoprotein cholesterol; HDL-c, high-densitylipoprotein cholesterol. Statistical differences were assessed by the Student's t test. 
(a)

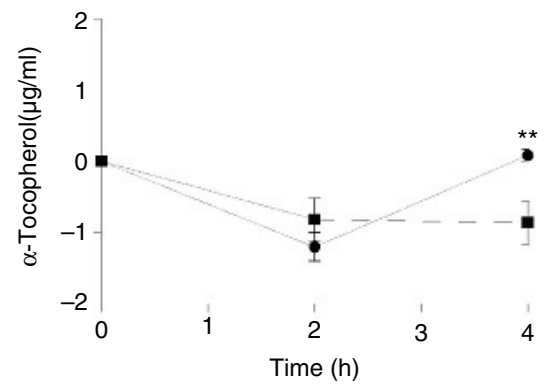

(c)

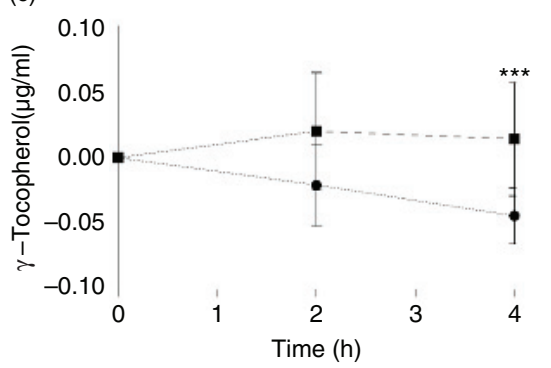

(e)

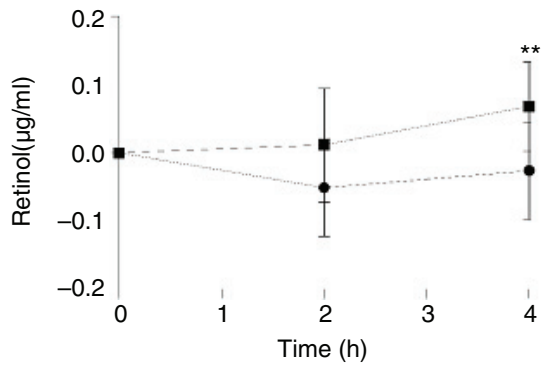

(b)

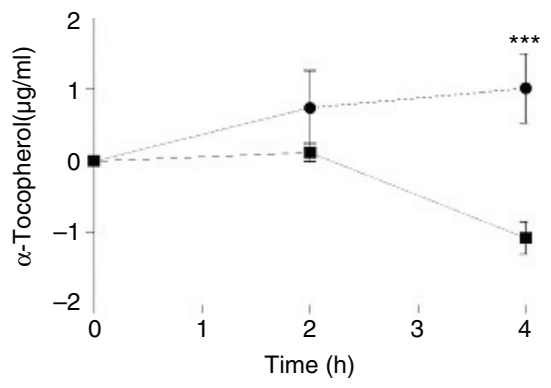

(d)

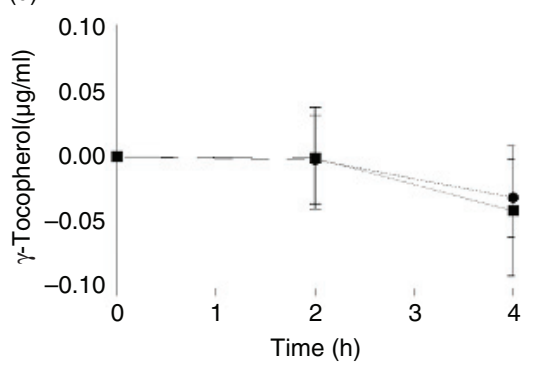

(f)

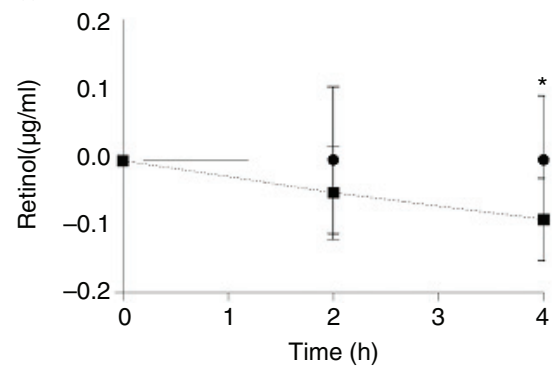

FIGURE 1. Serum postprandial $\alpha$-tocopherol, $\gamma$-tocopherol and retinol concentrations in the normal weight $(1 \mathrm{a}, 1 \mathrm{c}$ and $1 \mathrm{e})$ and obese ( $1 \mathrm{~b}, 1 \mathrm{~d}$ and $1 \mathrm{f})$ groups in the postprandial state. Values corresponding to the Mediterranean meal are represented by circle dots, whereas values corresponding to the Western meal are represented by square dots. Data are shown as mean \pm SEM. *: p $<0.05$, $* *: \mathrm{p}<0.01, * * *: \mathrm{p}<0.001$.

effect on VLDL and LDL oxidation, which was confirmed more recently by Van Hoydonck et al., (2004). However, Uzun et al., (2013) demonstrated that vitamin $\mathrm{C}$ or its combination with vitamin $\mathrm{E}$ significantly increased endothelial vasodilation in patients with coronary artery disease. Therefore, dietary supplementation with ascorbic acid might not have an impact on $\alpha$-tocopherol plasma levels, but they might act synergistically. This can also be the case of lycopene, which is found in relevant concentrations in tomato. Furhman et al., (2000) found that a combination of lycopene and $\alpha$-tocopherol showed a greater inhibition of LDL oxidation, compared to the compounds tested alone, confirming the synergistic effect.

Traber et al., (2015) reported that blood concentrations of $\alpha$-tocopherol are associated with the mechanisms which control lipid concentrations. These authors stated that postprandial $\alpha$-tocopherol remains in circulation for a longer time as the concentration of serum lipids increases, and that lipoprotein clearance is retarded in obese individuals. Very recently, these authors showed that subjects with metabolic syndrome displayed higher levels of biomarkers of oxidative stress and inflammation in plasma, suggesting that $\alpha$-tocopherol requirements had increased (Traber et al., 2017).

In our study, significant differences in plasma $\alpha$-tocopherol concentrations between meals were found only at 4 hours postprandially. At this time point, the size of triglyceride-rich lipoproteins (TRL), which are in fact the transporters of tocopherols and retinol, is key in atherogenesis (AmigoBenavent et al., 2016). Cabello-Moruno et al., (2014) 
(a)

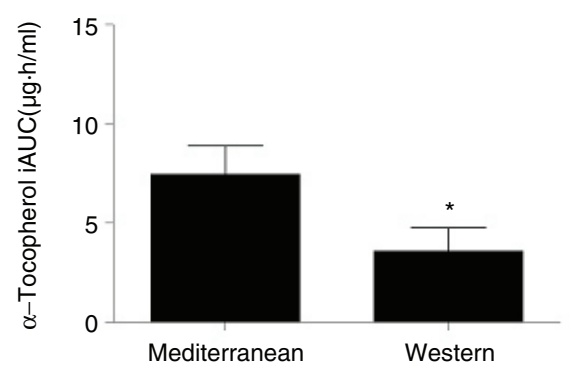

(c)

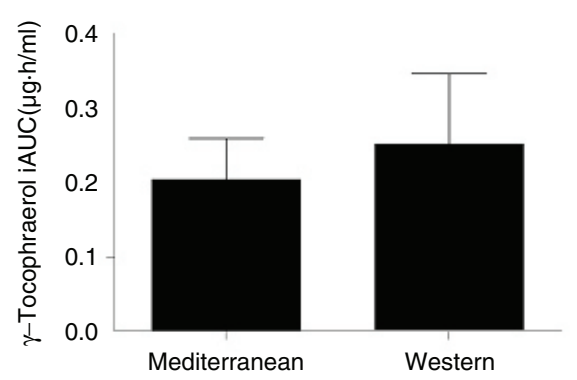

(e)

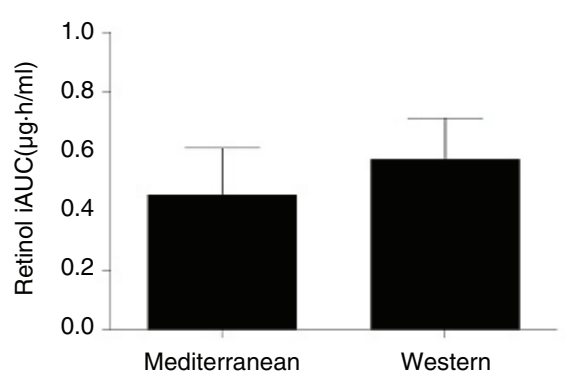

(b)

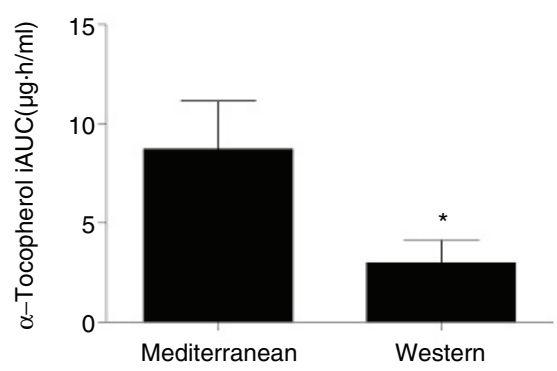

(d)

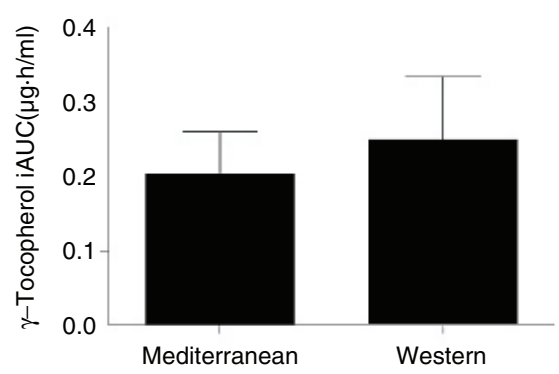

(f)

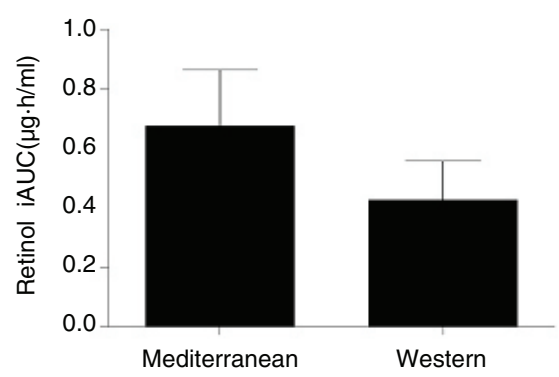

FIGURE 2. Incremental area under the curve (iAUC) values for serum postprandial $\alpha$-tocopherol, $\gamma$-tocopherol and retinol concentrations in the normal weight (2a, $2 \mathrm{c}$ and $2 \mathrm{e})$ and obese $(2 \mathrm{~b}, 2 \mathrm{~d}$ and $2 \mathrm{f})$ groups. Data are shown as mean \pm SEM. $*: \mathrm{p}<0.05$.

TABLE 4. Impact of body size, type of breakfast and their interaction on the postprandial incremental area under the curve (iAUC) values of the study endpoints.

\begin{tabular}{|c|c|c|c|c|c|c|c|c|c|}
\hline & \multicolumn{3}{|c|}{ Body size } & \multicolumn{3}{|c|}{ Breakfast } & \multicolumn{3}{|c|}{ Body size $x$ breakfast } \\
\hline & $\mathbf{F}$ & $\mathbf{p}$ & $\begin{array}{c}\text { Partial ETA } \\
\text { square }\end{array}$ & $\mathbf{F}$ & $\mathbf{p}$ & $\begin{array}{l}\text { Partial ETA } \\
\text { square }\end{array}$ & $\mathbf{F}$ & $\mathbf{p}$ & $\begin{array}{c}\text { Partial ETA } \\
\text { square }\end{array}$ \\
\hline$\alpha$-Tocopherol & 0.105 & 0.747 & 0.003 & 7.252 & 0.011 & 0.164 & 0.429 & 0.517 & 0.011 \\
\hline$\gamma$-Tocopherol & 0.001 & 0.980 & 0.000 & 0.401 & 0.531 & 0.011 & 0.000 & 0.988 & 0.000 \\
\hline Retinol & 0.059 & 0.809 & 0.001 & 0.173 & 0.680 & 0.004 & 1.396 & 0.244 & 0.034 \\
\hline
\end{tabular}

2x2 ANCOVA was applied on iAUC calculated from the postprandial profiles for each dependent variable, using body size (normal weight or obese) and breakfast (Mediterranean or Western) as independent variables. Partial ETA square was used to measure the effect size of the variable.

observed that triglyceride accumulation was greater when the cells were incubated with the postprandial TRL of intermediate size which were isolated at $4 \mathrm{~h}$ after a lipid load. In this regard, Armengol-Lopez et al., (2012) reported that chylomicron remnants (CMR), the most abundant TRL present in plasma at $4 \mathrm{~h}$ postprandially, are pro-inflammatory and are linked to atherogenic signalling in primary human monocytes. This implies an increased secretion of chemokines and cytokines, together with the production of the reactive oxygen species (ROS), which can be mitigated by $\alpha$-tocopherol (Godbout et al., 2004). 
In addition, $\alpha$-tocopherol has been shown to reduce the expression of scavenger receptors in macrophages (Teupser et al., 1999), which are essential for CMR uptake (Cabello-Moruno et al., 2014).

Therefore, we believe that postprandial $\alpha$-tocopherol may play a protective role in serum against atherosclerosis and that the Mediterranean breakfast favors it positively. In this regard, Carnevale et al., (2014) showed that when extra virgin olive oil was included in a Mediterranean diet, it significantly reduced postprandial oxidative stress and blocked the decrease in serum levels of vitamin $\mathrm{E}$, which is in agreement with our findings.

Nielsen et al., (2000), studied the effects in the postprandial state of two experimental meals containing different sources of dietary fats (sunflower oil, rapeseed oil, olive oil, palm oil or butter). They found that the postprandial plasma content of $\alpha$-tocopherol was significantly higher after the meal rich in olive and sunflower oils compared to the meal rich in palm oil but the $\gamma$-tocopherol content in VLDL was higher after the rapeseed oil meal. We did not find significant differences in serum $\gamma$-tocopherol concentrations after the consumption of the Mediterranean or Western breakfasts. Bates et al., (2004) reported strong correlations between higher plasma $\gamma$-tocopherol levels and obesity indexes, such as body weight, BMI and waisthip ratio. In addition, Hak et al., (2003) showed that men with high plasma $\gamma$-tocopherol levels were more likely to have an increased risk of myocardial infarction. Therefore, it seems that, in contrast to $\alpha$-tocopherol, higher plasma $\gamma$-tocopherol levels do not exert a protective or favorable effect against atherosclerosis. However, others have suggested that in healthy individuals, $\gamma$-tocopherol supplementation maintains vascular endothelial function during postprandial hyperglycemia, possibly attenuating lipid peroxidation (Mah et al., 2013).

We also were unable to find differences in serum postprandial retinol concentrations between the groups when the results were expressed as iAUC. Guerci et al., (2000), found reduced plasma retinyl palmitate at $4 \mathrm{~h}$ postprandially in obese individuals after an oral lipid challenge. They argued that since retinyl palmitate is considered a marker for intestinal TG-rich lipoproteins, the lower concentrations observed were predominantly due to CMR. Nevertheless, the lack of significant differences found in the present study for retinol is not surprising because the levels of this biomolecule are highly regulated and vary little with food intake, except in cases of supplementation or certain pathologies (Ascherio et al., 1992; Hak et al., 2003).

The $2 \times 2$ ANCOVA test employed in the present study showed that the type of breakfast affected the levels of $\alpha$-tocopherol in plasma but no influence of body size on the postprandial levels of tocopherols and retinol. Although, as stated above, Bates et al., (2004) reported that $\gamma$-tocopherol levels were related to obesity, correlations were weak in young individuals like the ones enrolled in our study. More importantly, they did not have postprandial data. In fact, to our knowledge, our study is the first one to report postprandial $\gamma$-tocopherol levels in obese individuals.

\section{CONCLUSIONS}

In conclusion, a Mediterranean-style breakfast increases serum $\alpha$-tocopherol, but not $\gamma$-tocopherol or retinol content in both lean and obese individuals in the postprandial state compared to a Westernstyle meal. Interestingly, the highest $\alpha$-tocopherol concentration was found $4 \mathrm{~h}$ after the meal intake, a time point at which CMR are most atherogenic. The well-known antioxidant properties of $\alpha$-tocopherol together with its reported abilities to down-regulate scavenger receptors in macrophages, could contribute to the protection of the Mediterranean-style meal against atherosclerosis in the postprandial state.

\section{ACKNOWLEDGMENTS}

This work was supported by the Spanish Ministry of Economy, Industry and Competitiveness under Grant AGL2011-23810.

\section{REFERENCES}

Amigo-Benavent M, Sinausia L, Montero E, Perona JS. 2016. Discordant ability of the triglyceride to apolipoprotein B ratio to predict triglyceride-rich lipoprotein particle size in normal-weight and obese men. Exp. Biol. Med. 241, 1772-1775. https://doi.org/10.1177/1535370216639394

Armengol Lopez S, Botham KM, Lawson C. 2012. The oxidative state of chylomicron remnants influences their modulation of human monocyte activation. Int. J. Vasc. Med. 2012. https://doi.org/10.1155/2012/942512

Ascherio A, Stampfer MJ, Colditz GA, Rimm EB, Litin L, Willett WC. 1992. Correlations of vitamin A and E intakes with the plasma concentrations of carotenoids and tocopherols among American men and women. J. Nutr. 122, 1792-1801.

Bach-Faig A, Geleva D, Carrasco J, Ribas-Barba L, SerraMajem L. 2006. Evaluating associations between Mediterranean diet adherence indexes and biomarkers of diet and disease. Public. Health Nutr. 9, 1110-1117. https:// doi.org/10.1017/S1368980007668499

Bates CJ, Mishra GD, Prentice A. 2004. $\gamma$-Tocopherol as a possible marker for nutrition-related risk: results from four National Diet and Nutrition Surveys in Britain. Br. J. Nutr. 92, 137. https://doi.org/10.1079/BJN20041156

Cabello-Moruno R, Perona JS, Ruiz-Gutierrez V. 2007. Influence of minor components of olive oils on the composition and size of TRLs and on macrophage receptors involved in foam cell formation. Biochem. Soc. Trans. 35, 470-471. https://doi.org/10.1042/BST0350470

Cabello-Moruno R, Sinausia L, Botham KM, Montero E, Avella M, Perona JS. 2014. Postprandial phase time influences the uptake of TAG from postprandial TAGrich lipoproteins by THP-1 macrophages. Br. J. Nutr. 112, 1469-1477. https://doi.org/10.1017/S00071145140 $0244 \mathrm{X}$ 
Carnevale R, Pignatelli P, Nocella C, Loffredo L, Pastori D, Vicario T, Petruccioli A, Bartimoccia S, Violi F. 2014. Extra virgin olive oil blunt post-prandial oxidative stress via NOX2 down-regulation. Atherosclerosis. 235, 649-658. https://doi.org/10.1016/j.atherosclerosis.2014.05.954

Friedewald WT, Levy RI, Fredrickson DS. 1972. Estimation of the Concentration of Low-Density Lipoprotein Cholesterol in Plasma, Without Use of the Preparative Ultracentrifuge. Clin. Chem. 18, 499-502.

Fuhrman B, Volkova N, Rosenblat M, Aviram M. 2000. Lycopene Synergistically Inhibits LDL Oxidation in Combination with Vitamin E, Glabridin, Rosmarinic Acid, Carnosic Acid, or Garlic. Antioxidants \& Redox Signaling 2, 491-506. https://doi.org/10.1089/15230860050192279

Godbout J, Berg BM, Kelley KW, Johnson RW. 2004. $\alpha$-Tocopherol reduces lipopolysaccharide-induced peroxide radical formation and interleukin- 6 secretion in primary murine microglia and in brain. J. Neuroimmunol. 149, 101-109. https://doi.org/10.1016/j.jneuroim.2003.12.017

Guerci B, Vergès B, Durlach V, Hadjadj S, Drouin P, Paul JL. 2000. Relationship between altered postprandial lipemia and insulin resistance in normolipidemic and normoglucose tolerant obese patients. Int. J. Obes. Relat. Metab. Disord. 24, 468-478

Hak AE, Stampfer MJ, Campos H, Sesso HD, Gaziano JM, Willett W, Ma J. 2003. Plasma carotenoids and tocopherols and risk of myocardial infarction in a low-risk population of US male physicians. Circulation 108, 802-807. https:// doi.org/10.1161/01.CIR.0000084546.82738.89

Hoydonck PGA van, Schouten EG, Manuel-y-Keenoy B, Campenhout A van, Hoppenbrouwers KPM, Temme EHM. 2004. Does vitamin $C$ supplementation influence the levels of circulating oxidized LDL, sICAM-1, sVCAM-1 and vWF-antigen in healthy male smokers? Eur. J. Clin. Nutr. 58, 1587-1593. https://doi.org/10.1038/ sj.ejcn. 1601990

Mah E, Noh SK, Ballard KD, Park HJ, Volek JS, Bruno RS. 2013. Supplementation of a $\gamma$-tocopherol-rich mixture of tocopherols in healthy men protects against vascular endothelial dysfunction induced by postprandial hyperglycemia. J. Nutr. Biochem. 24, 196-203. https://doi.org/10.1016/j. jnutbio.2012.04.015

Majerczyk M, Olszanecka-glinianowicz M, Puzianowska- M, Chudek J. 2016. Retinol-binding protein 4 (RBP4) as the causative factor and marker of vascular injury related to insulin resistance. Postepy. Hig. Med. Dosw. 70, 1267-1275.

Manuel-Y-Keenoy B, Campenhout A van, Vertommen J, Gaal L van, De Leeuw I. 2004. Evolution of serum $\alpha$-tocopherol in the postprandial and postabsorptive phases in type
1 diabetes mellitus. Ann. N. Y. Acad. Sci. 1031, 439-442. https://doi.org/10.1196/annals.1331.067

Maruyama C, Kikuchi N, Masuya Y, Hirota S, Araki R, Maruyama T. 2013. Effects of green-leafy vegetable intake on postprandial glycemic and lipidemic responses and $\alpha$-tocopherol concentration in normal weight and obese men. J. Nutr. Sci. Vitaminol. 59, 264-271. https://doi.org/10.3177/jnsv.59.264

Mody N. 2017. Alterations in vitamin A/retinoic acid homeostasis in diet-induced obesity and insulin resistance. Proc. Nutr. Soc. 76, 597-602. https://doi.org/10.1017/ S0029665117001069

Nielsen NS, Marckmann P, Høy C. 2000. Effect of meal fat quality on oxidation resistance of postprandial VLDL and LDL particles and plasma triacylglycerol level. Br. J. Nutr. 84, 855-863.

Plotnick GD, Corretti MC, Vogel RA 1997. Effect of Antioxidant Vitamins on the Transient Impairment of Endothelium-Dependent Brachial Artery Vasoactivity Following a Single High-Fat Meal. JAMA J. Am. Med. Assoc. 278, 1682-1686.

Spanish Agency for Consumer Affairs, Food Safety and Nutrition A. Spanish database of food composition. http:// www.bedca.net/bdpub/index.php. Accessed 11-29-2017.

Teupser D, Thiery J, Seidel D. 1999. Alpha-tocopherol downregulates scavenger receptor activity in macrophages. Atherosclerosis 144, 109-115.

Traber MG, Leonard SW, Bobe G, Fu X, Saltzman E, Grusak MA, Booth SL. 2015. $\alpha$-tocopherol disappearance rates from plasma depend on lipid concentrations: Studies using deuterium-labeled collard greens in younger and older adults. Am. J. Clin. Nutr. 101, 752-759. https://doi. org/10.3945/ajcn.114.100966

Traber MG, Mah E, Leonard SW, Bobe G, Bruno RS. 2017. Metabolic syndrome increases dietary alpha-tocopherol requirements as assessed using urinary and plasma vitamin E catabolites: a double-blind, crossover clinical trial. Am. J. Clin. Nutr. 105, 571-579. https://doi.org/10.3945/ ajcn.116.138495

Trpkovic A, Resanovic I, Stanimirovic J, Radak D, Mousa SA, Cenic-Milosevic D, Jevremovic D, Isenovic ER. 2015. Oxidized low-density lipoprotein as a biomarker of cardiovascular diseases. Crit. Rev. Clin. Lab. Sci. 52, 70-85. https://doi.org/10.3109/10408363.2014.992063

Uzun A, Yener U, Cicek OF, Yener O, Yalcinkaya A, Diken A, Ozkan T, Turkvatan A, Ulas M. 2013. Does vitamin C or its combination with vitamin $\mathrm{E}$ improve radial artery endothelium-dependent vasodilatation in patients awaiting coronary artery bypass surgery? Cardiovasc. J. Afr. 24, 255-259. https://doi.org/10.5830/CVJA-2013-046 